\section{Genotype-phenotype correlation of $\beta$-thalassemia spectrum of mutations in an Indian population}

\author{
Praveen Kishore Sahu, ${ }^{1,2}$ Sudhanshu \\ Shekhar Pati, ${ }^{1}$ Saroj Kanti Mishra ${ }^{3}$ \\ 1Department of Biochemistry and \\ Molecular Biology, Ispat General \\ Hospital, Rourkela, Orissa; ${ }^{2}$ Institute of \\ Bioinformatics and Biotechnology, \\ University of Pune; ${ }^{3}$ Department of \\ Internal Medicine, Ispat General Hospital, \\ Rourkela, India
}

\section{Abstract}

Coexistence of thalassemia, hemoglobinopathies and malaria has interested geneticists over many decades. The present study represents such a population from the eastern Indian state of Orissa. Children and their siblings $(n=38)$ were genotyped for $\beta$-thalassemia mutations and genotype-phenotype correlation was determined. The major genotype was IVS 1.5 mutation: $26 \%$ homozygous $(n=10)$ and $37 \%(n=14)$ double heterozygous with other mutations or hemoglobinopathies. Sickle hemoglobin was the major associated hemoglobinopathy $(\mathrm{n}=12,32 \%)$. Other mutations found were $\mathrm{Cd} 8 / 9, \mathrm{HbE}$ and $\mathrm{Cd} 41 / 42$. The study population did not contain any IVS 1.1 mutations which is the second major IndoAsian genotype. Genotype-phenotype correlation revealed that genotypes of IVS $1.5, \mathrm{Cd} 8 / 9$ Cd 41/42 alone or in association, exhibit severe, moderate and mild severity of thalassemia, respectively. Identification of the mutation at an early age as a part of new born screening and early intervention may help reduce the thalassemia-related morbidity.

\section{Introduction}

$\beta$-thalassemia is one of the most common monogenic disorder in the world. The incidence of this disease is high in many parts of the Indian subcontinent. ${ }^{1}$ There are 29.7 million carriers of $\beta$-thalassemia while approximately 7000 affected infants are born every year. ${ }^{2}$ More than 200 disease causing mutations have been described to date. ${ }^{3}$ There are five major and many rare $\beta$-thalassemia mutations seen in Asian Indians. ${ }^{4-9}$ The human $\beta$-globin protein of 146 amino acids is encoded by the globin gene with 3 exons (coding regions) with two major non-coding (introns) specified as intervening sequences IVS 1 and IVS 2 . Two major mutations are IVS $1.5(\mathrm{G} \rightarrow \mathrm{C})$ and IVS $1.1(\mathrm{G} \rightarrow \mathrm{T})$, lying on the IVS 1 intron; the former being the most common mutation in India. ${ }^{1,10,11}$ One of the deletion mutations ( 619 bp deletion) lies on the IVS 2 intron. The other prevalent mutations are $\mathrm{Cd} 8 / 9$ (+G frameshift mutation), $\mathrm{HbE}$ (Cd $26 \mathrm{G} \rightarrow \mathrm{A}$ ) on the first exon and $\mathrm{Cd} 41 / 42$ (-TCTT) on the second exon. Five major and many rare mutations have been characterized in various states of India, e.g. West Bengal, Haryana, Punjab, Uttar Pradesh, Bihar, Orissa., 1,7, Thalassemia is characterized by hemolytic anemia with dependence on regular blood transfusions for survival. ${ }^{12}$

About $62 \%$ of the present study population is native tribal (http://www.mrcindia.org/ rourkela.htm) and the rest migrant from adjoining districts. ${ }^{13}$ The study area is hyperendemic to malaria and also known for a prevalence of sickle hemoglobin. ${ }^{14,15}$ This supports the theory of evolution of hemoglobinopathies and thalassemic mutations along with malaria and their co-existence in the human gene pool, ${ }^{16}$ which may influence the overall genetic make-up of mutations inherited in the course of evolution. Furthermore, there is dearth of hospital based reports from this area concerning $\beta$-thalassemic gene mutations correlated with clinical severity. The classical $\beta$-thalassemia phenotypes can be modified by a number of environmental and genetic interacting factors, ${ }^{13}$ and, therefore, the genotype-phenotype relationship plays an important role in studying clinical severity. The present study deals with characterization of $\beta$-thalassemic gene mutations, which remain uncharacterized in this part of India, and also the genotype-phenotype correlations from western Orissa.

\section{Materials and Methods}

\section{Study area and ethical approval}

The study site was Rourkela, a city of western Orissa (Eastern India) situated at an average altitude of $200 \mathrm{~m}\left(21^{\circ} 35^{\prime}-22^{\circ} 35^{\prime} \mathrm{N}, 83^{\circ} 32^{\prime}\right.$ $\left.85^{\circ} 22^{\prime} \mathrm{E}\right)$. The Institutional Review Board, Ispat General Hospital, Rourkela, Orissa, India, approved this study and the Informed Consent Form (ICF) that was designed for this study.

\section{Clinical history and examination}

A total of 38 subjects were enrolled (age 6 months-4lyears, median age 8 years. There were 22 males and 16 females. A complete clinical history was recorded along with blood transfusion events. Patients were examined for organomegaly and growth parameters. Family history of any hemoglobinopathies, thalassemia, mortality due to such genetic disorders, etc., was recorded.
Correspondence: : Sudhanshu Shekhar Pati, Department of Biochemistry and Molecular Biology, Ispat General Hospital, Rourkela, Orissa, India.

Tel. +91.94370.40542 - Fax: +91.661.2642137.

E-mail: sspati@rediffmail.com

Key words: $\beta$-thalassemia mutations, genotypephenotype correlation, HbS, IVS 1.5 associated genotypes, malaria.

Contributions: SSP, SKM, conceptualization, experimental design, clinical history and examination, analysis of data, manuscript draft; PKS, experimental design, sample collection and study experiments, analysis of data, manuscript draft.

Conflict of interests: the authors report no potential conflict of interests.

Acknowledgments: the authors would thank Director Medical and Health Services, Ispat General Hospital for kind permission for the study and publication. The authors also thank Ms. Pavithra Iyer, IBB, University of Pune, for help in manuscript organization and editing.

Funding: this work was funded by the Department of Biotechnology (DBT) of the Indian Government. All the patients, guardians and the families who participated in this study are duly acknowledged.

Received for publication: 9 September 2011.

Revision received: 25 April 2012.

Accepted for publication: 30 April 2012.

This work is licensed under a Creative Commons Attribution NonCommercial 3.0 License (CC BYNC 3.0).

(C) Copyright P.K. Sahu et al., 2012

Licensee PAGEPress, Italy

Hematology Reports 2012; 4:e9

doi:10.4081/hr.2012.e9

\section{Sample collection}

After obtaining written consent on the ICF from each individual or parents of individuals under the age of 18 years, $3 \mathrm{~mL}$ of venous blood was drawn from each subject and stored in pretreated EDTA (ethylene-diamine-tetra-acetic acid) tubes, $1 \mathrm{~mL}$ of which was used for genomic DNA isolation and $2 \mathrm{~mL}$ for hemoglobin electrophoresis and estimation of complete blood count.

\section{Mutational analysis by} amplification refractory mutation system polymerase chain reaction

Genomic DNA was extracted using a commercial kit (Qiagen, Germany) according to the manufacturer's instructions. An ARMS (Amplification Refractory Mutation System) polymerase chain reaction (PCR) protocol was 
followed to detect any mutation as described by Old et al. ${ }^{8}$ Fragments were separated in ethidium bromide stained agarose gels and results were documented in a Gel Documentation system with DOC it-LS software (UVT, UK). PCR assays were reproduced at least twice within a period of 15 days for confirmation.

\section{Hemoglobin electrophoresis}

Hemoglobin electrophoresis was carried out in an automated electrophoresis system (Sebia, France) according to the manufacturer's instructions and fractions were analyzed using Phoresis software version 4.8.9 (Sebia, France). Standard sickle cell trait sample (with hemoglobin A, sickle cell hemoglobin, fetal hemoglobin and hemoglobin $\mathrm{A}_{2}$ fractions) accompanied with each run served as a positive control.

\section{Data analysis}

Single band for PCR assays with mutant primers was concluded as pure mutant (homozygous) whereas presence of bands in both wild-type and mutant PCR assay was inferred as a heterozygous mutant for the particular mutation concerned. Frequency distribution was calculated and comparisons were made in Excel spreadsheets (Microsoft).

\section{Results}

\section{Genotypic data}

In the present study, 38 individuals aged 6 months to 41 years were enrolled to study the characteristics of $\beta$-thalassemia mutations in Western Orissa, India, and also the genotypephenotype correlation. IVS 1.5 mutation was the predominant form in 24 (63.1\%) samples; $14(36.8 \%)$ of these were heterozygous mutant and 10 (26.3\%) were homozygous mutant alleles. The major associated hemoglobinopathy was sickle cell hemoglobin ( $\mathrm{HbS}$ ) with 8 patients as sickle $\beta^{0}$ thalassemia and 4 were sickle $\beta^{+}$thalassemia. Distribution of other major mutations can be seen in Figure 1A. Size of mutant alleles obtained corresponding to the mutations ranged from 234-488 bp (Table 1).

\section{Hemoglobin profiling}

Mean hemoglobin concentration was $6.58 \pm 0.77 \mathrm{gm} / \mathrm{dL}$ in the $\mathrm{HbS}-\beta$ thalassemia group. In the thalassemia group, hemoglobin concentration was $5.62 \pm 1.93,7.66 \pm 0.58$ and $10.44 \pm 1.33 \mathrm{gm} / \mathrm{dL}$ in severe, moderate and mild anemia, respectively. Either hepatosplenomegaly or splenomegally alone was found in 28 (73.7\%) subjects. Hemoglobin electrophoresis indicated that 12 (31.6\%) out of 38 subjects harbored $\mathrm{HbS}$. The overall distribution of hemoglobin fractions is listed in Tables 2 and 3.
Table 1. Analysis of fragment length of $\beta$-thalassemia mutant alleles.

\begin{tabular}{lcc} 
N. & Mutation type & Allele length in nucleotide base pairs \\
1 & IVS 1.1 & $488^{*}$ (wild) \\
2 & IVS 1.5 & 282 \\
\hline 3 & Cd $8 / 9$ & 234 \\
4 & Cd 41/42 & 456 \\
\hline 5 & HbE & 292 \\
\hline${ }^{*}$ No mutant alleles found for IVS 11 locus. &
\end{tabular}

${ }^{*}$ No mutant alleles found for IVS 1.1 locus.
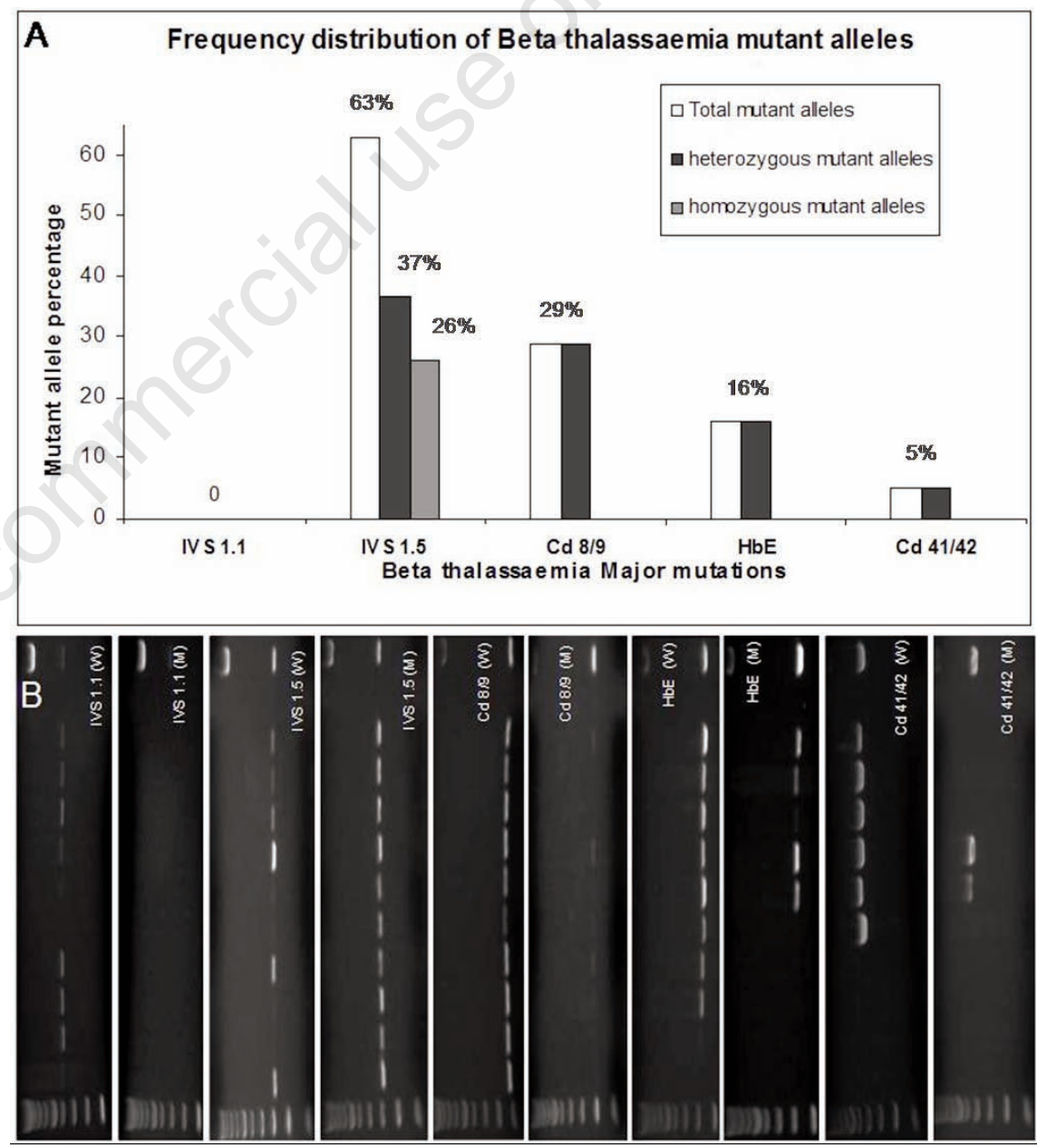

Figure 1. A) Frequency distribution of $\beta$-thalassemia mutant alleles, total mutant (white bars), heterozygous mutants (black bars) and homozygous mutants (gray bars); B) analysis of wild and mutant $\beta$-thalassemia alleles by polymerase chain reaction-amplification refractory mutation system assay. Each pair of gel pictures corresponds to the respective wild $(\mathrm{W})$ and mutant $(\mathrm{M})$ alleles detected by polymerase chain reaction-amplification refractory mutation system. 
Table 2. Sickle cell hemoglobin $\beta$-thalassemia. Clinical, hematologic and molecular data.

\begin{tabular}{|c|c|c|c|c|c|c|c|c|c|c|c|}
\hline N. & $\begin{array}{c}\text { Age } \\
\text { (years) }\end{array}$ & Sex & HbA & $\mathrm{HbF}$ & HbS & $\mathrm{HbA}_{2}$ & Organomegally & $\begin{array}{c}\text { Blood } \\
\text { transfusion } \\
\text { frequency } \\
\text { per year }\end{array}$ & Hemoglobin & $\begin{array}{c}\beta- \\
\text { thalassemia } \\
\text { mutation }\end{array}$ & Severity \\
\hline 1 & 4 & M & & 11.6 & 84.8 & 3.6 & Hepatosplenomegaly & 10 & 6 & IVS 1.5 & Severe \\
\hline 2 & 12 & M & & 11.6 & 83.9 & 4.5 & Splenomegaly & 8 & 7 & IVS 1.5 & Severe \\
\hline 3 & 4 & $\mathrm{~F}$ & & 14.7 & 80.6 & 4.7 & Splenomegaly & 11 & 5.6 & IVS 1.5 & Severe \\
\hline 4 & 8 & $\mathrm{~F}$ & & 17.5 & 77.2 & 5.3 & Splenomegaly & 9 & 6.6 & IVS 1.5 & Severe \\
\hline 5 & 18 & $\mathrm{~F}$ & & 19.3 & 76.4 & 4.3 & Hepatosplenomegaly & 8 & 5.3 & IVS 1.5 & Severe \\
\hline 6 & 6 & $\mathrm{~F}$ & & 22.5 & 73.1 & 4.4 & Splenomegaly & 7 & 7.8 & $\mathrm{Cd} 8 / 9$ & Severe \\
\hline 7 & 8 & M & & 23 & 72.4 & 4.6 & Mild hepatosplenomegaly & 6 & 6 & $\mathrm{Cd} 8 / 9$ & Severe \\
\hline 8 & 9 & $\mathrm{~F}$ & & 25.5 & 69.6 & 4.9 & Splenomegaly & 8 & 6.5 & IVS 1.5 & Severe \\
\hline 9 & 0.6 & M & 7.2 & 12.3 & 77.3 & 3.2 & Hepatosplenomegaly & 3 & 6.6 & IVS 1.5 & Severe \\
\hline 10 & 15 & $\mathrm{~F}$ & 14 & 12 & 69.5 & 4.5 & Mild splenomegaly & 9 & 7.8 & IVS 1.5 & Severe \\
\hline 11 & 12 & $\mathrm{~F}$ & 11.5 & 18.2 & 65.7 & 4.6 & Spelnomegaly, huge hepatomegaly & 7 & 6.8 & IVS 1.5 & Severe \\
\hline 12 & 16 & $\mathrm{~F}$ & 17.1 & 28.9 & 49.4 & 4.6 & Splenomegally & 6 & 7 & IVS 1.5 & Severe \\
\hline
\end{tabular}

$\mathrm{HbA}$, hemoglobin A; $\mathrm{HbF}$, fetal hemoglobin; $\mathrm{HbS}$, sickle cell hemoglobin; $\mathrm{HbA}_{2}$, hemoglobin $\mathrm{A}_{2}$.

Table 3. $\beta$-thalassemia. Clinical, hematologic and molecular data.

\begin{tabular}{|c|c|c|c|c|c|c|c|c|c|c|c|}
\hline N. & $\begin{array}{c}\text { Age } \\
\text { (years) }\end{array}$ & Sex & HbA & $\mathrm{HbF}$ & $\mathrm{HbA}_{2}$ & Organomegally & $\begin{array}{c}\text { Blood } \\
\text { transfusion } \\
\text { per year }\end{array}$ & Hb & $\begin{array}{c}\beta- \\
\text { thalassemia } \\
\text { mutation }\end{array}$ & Phenotype & Severity \\
\hline 1 & 41 & M & 94.2 & 1.6 & 4.2 & Nil & Nil & 11 & $\mathrm{Cd} 8 / 9$ & HT & Mild \\
\hline 2 & 1 & M & 22.9 & 72.8 & 4.3 & Hepatosplenomegaly & 9 & 6.5 & IVS 1.5 & $\mathrm{HM}$ & Severe \\
\hline 3 & 5 & M & 12.5 & 83.1 & 4.4 & Hepatosplenomegaly & 10 & 5.6 & IVS 1.5 & $\mathrm{HM}$ & Severe \\
\hline 4 & 8 & M & 28.5 & 67.1 & 4.4 & № (Splenectomy) & 6 & 6.5 & IVS 1.5 & HM & Severe \\
\hline 5 & 6 & $\mathrm{M}$ & 23.5 & 35.6 & 40.9 & Splenomegaly & 3 & 7 & IVS $1.5, \mathrm{HbE}$ & CHT & Moderate \\
\hline 6 & 5 & M & 6.7 & 88.6 & 4.7 & Splenomegaly & 8 & 5 & IVS 1.5 & HM & Severe \\
\hline 7 & 5 & $\mathrm{~F}$ & 38.3 & 26.6 & 35.1 & Hepatosplenomegaly & Nil & 10 & $\mathrm{Cd} 8 / 9, \mathrm{Hb} \mathrm{E}$ & CHT & Mild \\
\hline 8 & 5 & M & 13.2 & 82.9 & 3.9 & Hepatosplenomegaly & 11 & 5 & IVS 1.5 & $\mathrm{HM}$ & Severe \\
\hline 9 & 25 & $\mathrm{~F}$ & 93.4 & 2.3 & 4.3 & Nil & Nil & 11 & $\mathrm{Cd} 8 / 9$ & HT & Mild \\
\hline 10 & 22 & $\mathrm{~F}$ & 89.4 & 6.8 & 3.8 & Nil & Nil & 10.6 & $\mathrm{Cd} 8 / 9$ & HT & Mild \\
\hline 11 & 13 & $\mathrm{M}$ & 24.2 & 70.7 & 5.1 & Hepatosplenomegaly & 3 & 8 & $\mathrm{HbE}, \mathrm{Cd} 41 / 42$ & CHT & Moderate \\
\hline 12 & 22 & $\mathrm{~F}$ & 91.9 & 5.7 & 4.4 & Nil & Nil & 10.4 & $\mathrm{Cd} 8 / 9$ & HT & Mild \\
\hline 13 & 12 & M & 2.5 & 93.6 & 3.9 & Splenomegaly & 9 & 6 & IVS 1.5 & HM & Severe \\
\hline 14 & 5 & M & 6.9 & 88.8 & 4.3 & Splenomegaly & 12 & 5 & IVS 1.5 & HM & Severe \\
\hline 15 & 4 & $\mathrm{~F}$ & 90.6 & 4.6 & 4.8 & Nil & Nil & 11 & $\mathrm{Cd} 8 / 9$ & HT & Mild \\
\hline 16 & 9 & M & 7.2 & 89 & 3.8 & Mild splenomegaly & 8 & 4 & IVS 1.5 & HM & Severe \\
\hline 17 & 8 & M & 8.7 & 87.1 & 4.2 & Nil & 4 & 9.8 & $\mathrm{HbE}$ & HT & Mild \\
\hline 18 & 3 & M & 5 & 90.7 & 4.3 & Hepatosplenomegaly & 11 & 6.4 & IVS 1.5 & HM & Severe \\
\hline 19 & 2 & M & 17.4 & 78 & 4.6 & Mild splenomegaly & 6 & 7.3 & IVS $1.5, \mathrm{Cd} 8 / 9$ & CHT & Severe \\
\hline 20 & 4 & M & 2.8 & 93 & 4.2 & Splenomegaly & 10 & 4.5 & IVS 1.5 & HM & Severe \\
\hline 21 & 12 & $\mathrm{~F}$ & 70 & 3.2 & 26.8 & Splenomegaly & Nil & 9.5 & IVS 1.5 & HT & Mild \\
\hline 22 & 8 & M & 62 & 3.2 & 34.8 & Mild splenomegaly & Nil & 10 & $\mathrm{HbE}$ & HT & Mild \\
\hline 23 & 29 & M & 6.2 & 31 & 62.8 & Nil & Nil & 10.5 & $\mathrm{HbE}$ & $\mathrm{HT}$ & Mild \\
\hline 24 & 25 & $\mathrm{~F}$ & 14 & 25 & 61 & Splenomegaly & 2 & 8 & IVS 1.5,Cd41/42 & CHT & Moderate \\
\hline 25 & 36 & M & 94.7 & 1.5 & 3.8 & Nil & Nil & 10.5 & $\mathrm{Cd} 8 / 9$ & HT & Mild \\
\hline 26 & 32 & $\mathrm{~F}$ & 94 & 2.3 & 3.7 & Nil & Nil & 11 & $\mathrm{Cd} 8 / 9$ & HT & Mild \\
\hline
\end{tabular}

$\mathrm{HbA}$, hemoglobin $\mathrm{A} ; \mathrm{HbF}$, fetal hemoglobin; $\mathrm{HbS}$, sickle cell hemoglobin; $\mathrm{HbA}_{2}$, hemoglobin $\mathrm{A}_{2}$; $\mathrm{HT}$, heterozygous; $\mathrm{HM}$, homozygous; $\mathrm{CHT}$, compound heterozygous. 


\section{Genotype-phenotype correlation}

Tables 2 and 3 show the genotypes of IVS1.5, $\mathrm{HbE}, \mathrm{Cd} 8 / 9$ and $\mathrm{Cd} 41 / 42$ alone or in association with $\mathrm{HbS}$ and their phenotypes expressed in terms of clinical severity, i.e. mild, moderate and severe. IVS 1.5 associated genotype exhibited severe to moderate level phenotypes with IVS 1.5 homozygous alone $(\mathrm{n}=10)$ and IVS 1.5 with $\mathrm{HbS}(\mathrm{n}=10)$ being the predominant association. $\mathrm{HbE}$ associated genotype presented minimal severity whereas $\mathrm{Cd} 8 / 9$ associated genotype showed moderate severity.

\section{Discussion}

The present study confirmed distribution of $\beta$-thalassemia along with a genotype-phenotype correlation in an Indian population coexistent with $H b S$ gene and high malarial incidence. Besides presence of other mutations, the present study demonstrated IVS 1.5 mutation as the predominant genotype (63\%) in this population from Western Orissa, India. This is comparable with earlier findings. ${ }^{1,17}$ This mutation, however, was largely associated with $\mathrm{HbS}$, presenting severe thalassemic phenotypic expression in the study subjects (Table 2). Although a high rate of organomegaly was seen among the study subjects, an early start of transfusion could have prevented hypersplenism and red cell sensitization. The second major mutation found in Indo-Asians, i.e. IVS1.1, was not detected in this population; a rare observation in contrast to other parts of India, ${ }^{1}$ but in agreement with a recent report. ${ }^{11}$

With respect to $\beta$-thalassemia, $\mathrm{HbE}$ and $\mathrm{HbS}$, aberrant heterosis in hemoglobinopathies was demonstrated in an earlier study, ${ }^{18}$ which highlighted co-inheritance of these genes seen earlier in southern and western Orissa. Though small in size, our study throws some light on a genotype-phenotype correlation and therefore on the diagnostic capacity of associative genotypes of $\beta$-thalassemia mutations (Tables 2 and 3). This may serve as a tool to predict clinical severity if detected in early life. The correlation can add to the existing knowledge to widen our understanding of the varied clinical presentation, phenotypic diversity and genotypic heterogeneity. This will help early intervention on patients at high risk and promote prevention by genetic counseling. Our data suggest that prediction of mild phenotypes may avoid unnecessary transfusion. ${ }^{17}$ We believe that a prenatal diagnosis plan, or at least newborn screening for molecular markers, can lead to better outcomes in developing countries with thalassemia endemicity.

\section{References}

1. Verma IC, Saxena R, Thomas E, Jain PK. Regional distribution of $\beta$-thalassemia mutations in India. Hum Genet 1997;100: 109-13.

2. UNICEF. The state of the world children. Oxford: Oxford University Press; 1996.

3. Cao A, Galanello R. Beta-thalassemia. In: Pagon RA, Bird TC, Dolan CR, Stephens K. GeneTest reviews, genetics in medicine. Philadelphia: Lippincott Williams \& Wilkins; 2010. pp 61-76.

4. Kazazian HH Jr, Orkin SM, Antonarakis SE, et al. Molecular characterization of seven $\beta$-thalassemia mutations in Asian Indians. EMBO J 1984;3:593-6.

5. Wong C, Antonarakis SE, Goff SC, et al. On the origin and spread of $\beta$-thalassemia: recurrent observation of four mutations in different ethnic groups. Proc Natl Acad Sci USA 1986;83:6529-32.

6. Thein SL, Hesketh C, Wallace RB, Weatherall DJ. The molecular basis of thalassemia major and thalassemia intermedia in Asian Indians: application to prenatal diagnosis. Br J Haematol 1988;70:22531.

7. Varawalla NY, Old JM, Sarkar R, et al. The spectrum of $\beta$-thalassemia mutations on the Indian subcontinent: the basis for prenatal diagnosis. Br J Haematol 1991;78: 242-7.
8. Old JM, Varawalla NY, Weatherall DJ. Rapid detection and prenatal diagnosis of beta-thalassemia: studies in Indian and Cypriot population in the UK. Lancet 1990;336:834-7.

9. Jain PK, Dozy AM, Verma IC, Chehab FF. A new frameshift mutation, insertion of ATCT, at codon 48 in the $\beta$-globin gene causes $\beta$-thalassemia in an Indian proband. Hum Mutat 1994;3:397-8.

10. Black ML, Sinha S, Agarwal S, et al. A descriptive profile of $\beta$-thalassemia mutations in India, Pakistan and Sri Lanka. J Commun Genet 2010;1:149-57.

11. Sinha S, Black ML, Agarwal S, et al. Profiling $\beta$-thalassemia mutations in India at state and regional levels: implications for genetic education, screening and counseling programs. HUGO J 2009;3:5162.

12. Weatherall DJ, Clegg JB. In: The thalassemia syndromes. Boston: Blackwell; 1981.

13. Cao A, Galanello R, Rosatelli M. Genotypephenotype correlations in thalassemias. Blood Rev 1994;8:1-12.

14. Sharma SK, Tyagi PK, Pradhan K, et al. Epidemiology of malaria transmission in forest and plain ecotype villages in Sundergarh district, Orissa, India. Trans R Soc Trop Med Hyg 2006;100:917-25.

15. Pati SS, Panigrahi J, Mishra SK, et al. Severe complications and death in cases with sickle cell trait. Ann Trop Med Parasitol 2005;99:317-20.

16. Kwiatkowski DP. How malaria has affected the human genome and what human genetics can teach us about malaria. Am J Hum Genet 2005;77:171-90.

17. Greer JP, Foerster J, Lukens JN. Wintrobe's clinical hematology, 11th ed. Philadelphia: Lippincott Williams and Wilkins; 2004. p 1329.

18. Balgir RS. Aberrant heterosis in hemoglobinopathies with special reference to $\beta$ Thalassemia and structurally abnormal hemoglobins $\mathrm{E}$ and $\mathrm{S}$ in Orissa, India. J Clin Diagnostic Res 2007;1:122-30. 